Original article

\title{
Design and evaluation of herbal hepatoprotective formulation against paracetamol induced liver toxicity
}

\author{
Arti Gupta ${ }^{a}, *$, Navin R. Sheth ${ }^{b}$, Sonia Pandey ${ }^{a}$, Dinesh R. Shah ${ }^{a}$, Jitendra S. Yadav ${ }^{c}$ \\ ${ }^{a}$ Maliba Pharmacy College, Bardoli, Gujarat, India \\ ${ }^{\mathrm{b}}$ Department of Pharmacognosy, Saurashtra University, Rajkot, Gujarat, India \\ ${ }^{\mathrm{c}}$ Department of Pharmaceutics, Vidya Bharti Trust College of Pharmacy, Bardoli, Gujarat, India
}

\section{A R T I C L E I N F O}

\section{Article history:}

Received 19 August 2013

Accepted 11 December 2013

Available online 7 January 2014

\section{Keywords:}

Butea monosperma

Bauhinia variegata

Ocimum gratissimum

Polyherbal formulation

Hepatoprotective activity

\begin{abstract}
A B S T R A C T
Aim: To isolate and identify the quercetin from polyherbal hepatoprotective formulation. Polyherbal formulations were developed by using five bioactive fractionated extracts of Butea monosperma, Bauhinia variegata and Ocimum gratissimum for treatment of liver disorders by exploiting the knowledge of traditional system of medicine and evaluated for hepatoprotective activity using acute liver toxicity model of paracetamol induced liver damage in rats.

Methods: Major active fractions were isolated by solvent fractionation and quantified by HPTLC method. Two polyherbal tablet formulations were developed by the wet granulation method using microcrystalline cellulose, aerosil and other excipients and subjected for physicochemical evaluation to assess physical stability followed by pharmacological screening. The prepared tablets were finally subjected to stability testing to assess its shelf-life. The rats were monitored for change in liver morphology, biochemical parameters like serum glutamate pyruvate transaminase (SGPT), serum glutamate oxaloacetate transaminase (SGOT), alkaline phosphatase (ALP) and total bilirubin for polyherbal tablet formulation at $50 \mathrm{mg} / \mathrm{kg}$ and polyherbal tablet formulation at $100 \mathrm{mg} / \mathrm{kg}$.

Results: Active principle was isolated, quantified by HPTLC and characterized with IR. Both formulations showed significant hepatoprotective activity. The histological studies were also support the biochemical parameters. From the results of biochemical analysis and histopathological studies, it can be accomplished that polyherbal tablet formulation at $100 \mathrm{mg} / \mathrm{kg}$ can be effectively formulated into a suitable dosage form with added benefit of no side effects for control and cure of chronic ailments like liver disorders. A comparative histopathological study of liver exhibited almost normal architecture as compared to toxicant group.

Conclusion: Biochemical marker showed improved results for polyherbal tablet formulation at $100 \mathrm{mg} /$ $\mathrm{kg}$. Polyherbal tablet formulation contains a potent hepatoprotective agent suggested to be a flavone concentrated in polyherbal formulation which may find clinical application in amelioration of paracetamol induced liver damage.
\end{abstract}

Copyright $\odot$ 2013, InPharm Association, Published by Reed Elsevier India Pvt. Ltd. All rights reserved.

\section{Introduction}

In the last few decades there has been an exponential growth in the field of herbal medicine. It is getting popularized in developing and developed countries owing to its natural origin and lesser side effects. ${ }^{1}$ Herbal remedies provide rational means for the treatment of many internal diseases which are considered to be stubborn and incurable in other system of medicines. It lays a great deal of

\footnotetext{
* Corresponding author. Maliba Pharmacy College, Gopal Vidhya Nagar, Bardoli, Gujarat, India.

E-mail address: arti.gupta@utu.ac.in (A. Gupta).
}

emphasis upon the maintenance of positive health of an individual. It thus aims at both the prevention and cure of diseases. ${ }^{2}$ An ancient system of traditional medicines like Siddha, Ayurveda, Chinese and Japanese have been adopted for the diagnosis, prevention and treatment of liver disorders. This attempts to prove scientific insight behind the traditional adaption. Less toxicity, better therapeutic effect, good patient compliance and cost effectiveness are the reasons for choosing drug from natural origin. ${ }^{3}$

Ayurvedic and herbal medicinal products contain a combination of number of chemical compounds that may give the anticipated activity in combination. ${ }^{4}$

The development of a stable polyherbal formulation is a challenging task because of the large number of varied chemical 
compounds present in the different medicinal plants. Hence, the entire herbal drug or herbal drug preparation is regarded as active drug substance, regardless of whether constituents with defined therapeutic activity are known and unfortunately, the quality of a majority of them remains uncontrolled. All these issues have been acknowledged in the draft of the Strategic Plan for Regional Traditional Medicine of the World Health Organization. ${ }^{5}$

A great deal of research has been carried out to evaluate scientific basis for the claimed hepatoprotective activity of herbal agents as in the form of polyherbal formulation. Butea monosperma (Fabaceae) is commonly known as palas and is beneficial in conditions of liver disease and inflammation. ${ }^{6}$ The plant mainly contains flavones (quercetin), ${ }^{7}$ kino-tannic acid, and gallic acid. ${ }^{8}$

Bauhinia variegata (Leguminosae) commonly known as Kachnar, is found to be beneficial in Ayurveda as tonic to the liver and antiinflammatory, healing activity, antioxidant activity. ${ }^{9}$ B. variegata has been reported to contain quercetin, rutin, apigenin and apigenin 7-O-glucoside. Flavonoids and quercetin in particular are potent antioxidants and are known to modulate the activities of various enzyme systems due to their interaction with various biomolecules. ${ }^{10}$

Ocimum gratissimum Linn. (Lamiaceae) is known traditionally for its effect in liver diseases, inflammation and antibacterial activity. ${ }^{11}$ The active constituents, flavonoids, quercetin 3-O-glucoside, rutin, kaempferol 3-O-rutinoside and vicenin-2 were identified. $^{12}$

Quercetin (flavonoid) and ursolic acid (triterpenic acid), well known for its hepatoprotective effects in both acute chemically induced liver injury and chronic liver fibrosis and cirrhosis. ${ }^{13}$

Ursolic acid was previously determined in dichloromethane and ethyl acetate fractions of methanolic extract of $O$. gratissimum and in developed herbal hepatoprotective tablet in my previous article. $^{8}$

The present study was designed to develop polyherbal formulation taking advantage of ayurvedic principles, where herbal ingredients present in plants are known to have specific activity in modulation of liver disease condition so the present study was undertaken to evaluate the hepatoprotective effect of developed polyherbal formulation in which acute hepatotoxicity was induced by paracetamol treatment.

\section{Material and methods}

\subsection{Material}

The fresh bark of B. monosperma, B. variegata and fresh leaves of O. gratissimum were collected from Maliba Pharmacy College Campus. Voucher specimen (No: MPC/13032010/01, 02 and 03) has been deposited in the Department of Bioscience, Veer Narmad South Gujarat University, Surat, India. Rats were used for hepatoprotective study, with prior approval from the Institutional Animal Ethical Committee (Registration No. 717/02/a/CPCSEA/30 Jan 2010) of Maliba Pharmacy College, Uka Tarsadia University.

\subsection{Extraction}

All the three crude drugs were extracted with alcohol and then alcoholic extract of each plant was subjected to solvent fractionation.

B. monosperma: Ethanolic extract obtained was fractionated with petroleum ether, benzene, chloroform and acetone (AcO) in the order of increasing polarity to obtain respective fractions. ${ }^{14}$

B. variegata: Methanolic extract was fractionated with hexane, ethyl acetate (EtOAc) and n-butanol (n-ButOH) in the order of their increasing polarity to obtain respective fractions. ${ }^{15}$ o. gratissimum: Methanolic extract of 0 . gratissimum was fractionated with hexane, dichloromethane(DCM), ethyl acetate (EtOAc) and methanol in the order of their increasing polarity to obtain respective fractions. ${ }^{16}$

\subsection{Establishment of qualitative phytoprofile of fractionated extracts}

\subsubsection{Qualitative phytochemical analysis}

Each fraction was subjected to various qualitative chemical tests using reported methods to determine the presence or absence of metabolites viz., alkaloids, tannins, flavonoid, steroid, terpenoids and phenolic compounds etc. ${ }^{17}$

\subsubsection{Chemical test for flavonoids in each fraction}

i. Dilute ammonia solution $5 \mathrm{~mL}$ was added to a portion of each extract fraction followed by addition of concentrated $\mathrm{H}_{2} \mathrm{SO}_{4}$ a yellow coloration observed indicated the presence of flavonoids.

ii. The yellow coloration disappeared on standing. Few drops of $1 \%$ aluminum solution were added to a portion of each fraction. A yellow coloration was observed indicating the presence of flavonoid. $^{18}$

\subsection{Qualitative phytochemical analysis}

\subsubsection{Determination of total phenols}

Acetone fraction of $B$. monosperma, ethyl acetate and n-butanol fractions of $B$. variegata and dichloromethane and ethyl acetate fractions of 0 . gratissimum $(100 \mu \mathrm{L})$ of each fraction were mixed with $1 \mathrm{~mL}$ Folin-Ciocalteu reagent and $0.8 \mathrm{~mL}$ of $7.5 \% \mathrm{Na}_{2} \mathrm{CO}_{3}$. The resultant mixture of each fraction was measured at $765 \mathrm{~nm}$ after $2 \mathrm{~h}$ at room temperature. The mean of three readings was used and the total phenolic content was expressed in milligram of gallic acid equivalents $/ 1 \mathrm{~g}$ extract. The coefficient of determination was found to be $r^{2}=0.992 .{ }^{19}$

\subsubsection{Determination of total flavonoids}

Standard quercetin was used to make the calibration curve $[0.04$, $0.02,0.0025$ and $0.00125 \mathrm{mg} / \mathrm{mL}$ in $80 \%$ ethanol (v/v)]. The standard solutions and acetone fraction of $B$. monosperma, ethyl acetate and n-butanol fractions of $B$. variegata and dichloromethane and ethyl acetate fractions of 0 . gratissimum $(0.5 \mathrm{~mL})$ of each fraction was mixed with $1.5 \mathrm{~mL}$ of $95 \%$ ethanol (v/v), $0.1 \mathrm{~mL}$ of $10 \%$ aluminum chloride (w/v), $0.1 \mathrm{~mL}$ of $1 \mathrm{~mol} / \mathrm{L}$ sodium acetate and $2.8 \mathrm{~mL}$ water. The volume of $10 \%$ aluminum chloride was substituted by the same volume of distilled water in blank. After incubation at room temperature for $30 \mathrm{~min}$, the absorbance of the reaction mixture of each fraction and standard solution was measured at $415 \mathrm{~nm}$. The mean of three readings was used and the total flavonoid content was expressed in milligram of quercetin equivalents $/ 1 \mathrm{~g}$ extract. The coefficient of determination was $r^{2}=0.990 .^{20}$

\subsection{Preparation of formulations}

Polyherbal tablet formulations (PTF) contain the crude raw materials of $B$. monosperma, $B$. variegata and $O$. gratissimum prepared by wet granulation method using suitable excipients like microcrystalline cellulose, starch, crospovidone, aerosil and magnesium stearate. ${ }^{21}$ The composition of tablet formulations is shown in Table 1. 


\subsection{Quantification of quercetin by HPTLC}

A Camag HPTLC system was used with beam size of $0.4 \times 0.4 \mathrm{~mm}$, and wavelength of $380 \mathrm{~nm}$. Silica gel $60 \mathrm{~F} 254$ $(20 \times 20 \mathrm{~cm}, 0.25-\mathrm{mm}$ thick, Merck) plates were used for HPTLC. Samples were applied ( $15 \mathrm{~mm}$ from the bottom edge of the plate) in the form of $6 \mathrm{~mm}$ bandwidth with Hamilton syringes using Linomat V applicator. A constant application rate of $150 \mathrm{nl} / \mathrm{s}$ was supplied and a space of $10 \mathrm{~mm}$ was kept between two bands. The mobile phase constituted of toluene:ethyl acetate:formic acid, 5:4:0.1 ( $/ \mathrm{v} / \mathrm{v})$. Linear ascending development was carried out in a twin trough glass chamber saturated with mobile phase. The optimized saturation time for mobile phase was $30 \mathrm{~min}$ at room temperature $\left(25^{\circ} \mathrm{C} \pm 2{ }^{\circ} \mathrm{C}\right)$ with relative humidity of $55 \pm 5 \%$. After developing TLC plate a current of air was used to dry it. Densitometric scanning was performed on Camag TLC scanner III in absorbance mode at $380 \mathrm{~nm}$. The source of light was deuterium beam. The quantitative determination was performed by using the external calibration method. A stock solution of quercetin $(500 \mu \mathrm{g} /$ $\mathrm{mL}$ ) was prepared in methanol. Different volume of stock solution i.e. $0.5,1.0,1.5,2.0,2.5 \mathrm{in} \mu \mathrm{g} / \mathrm{spot}$ were spotted on TLC plate of 200 , 400, 800, 1600 and $3200 \mathrm{ng} /$ spot of quercetin. Calibration curve range $(0.5-2.5 \mu \mathrm{g} / \mathrm{spot})$ for quercetin was found to be linear. The data of peak areas plotted against the corresponding concentrations were collected. To determine the content of quercetin in extract $10 \mathrm{mg}$ of each fraction was transferred in $10 \mathrm{~mL}$ volumetric flask containing $8 \mathrm{~mL}$ methanol, vortexed for $10 \mathrm{~min}$ and diluted to $10 \mathrm{~mL}$ with methanol. The resulting solution was filtered through Whatman filter paper. The $15 \mu \mathrm{L}$ of the filtered solution was applied on TLC plate subsequently developed and scanned as described above.

\subsection{Evaluation of power blends}

The polyherbal tablets were prepared by wet granulation method hence micromeritic studies (angle of repose, bulk density, tapped density, \% compressibility) were evaluated prior to punching of tablets.

\section{Table 1}

Composition of polyherbal tablets formulations (PTF).

\begin{tabular}{|c|c|c|c|}
\hline \multirow[t]{2}{*}{ Sr. no } & \multirow[t]{2}{*}{ Ingredients } & \multirow{2}{*}{$\begin{array}{l}\text { PTF-1 } \\
\text { Quantity } \\
\text { (mg/tablet) }\end{array}$} & \multirow{2}{*}{$\begin{array}{l}\text { PTF-2 } \\
\begin{array}{l}\text { Quantity } \\
\text { (mg/tablet) }\end{array}\end{array}$} \\
\hline & & & \\
\hline & Dry mix & & \\
\hline 1 & $\begin{array}{l}\text { Acetone fraction of } \\
\text { Butea monosperma }\end{array}$ & 10 & 20 \\
\hline 2 & $\begin{array}{l}\text { Ethyl acetate fraction } \\
\text { of Bauhinia variegata }\end{array}$ & 10 & 20 \\
\hline 3 & $\begin{array}{l}\text { n-Butanol fraction of } \\
\text { Bauhinia variegata }\end{array}$ & 10 & 20 \\
\hline 4 & $\begin{array}{l}\text { Dichloromethane of } \\
\text { Ocimum gratissimum }\end{array}$ & 10 & 20 \\
\hline 5 & $\begin{array}{l}\text { Ethyl acetate fraction } \\
\text { of Ocimum gratissimum }\end{array}$ & 10 & 20 \\
\hline 6 & $\begin{array}{l}\text { Microcrystalline } \\
\text { cellulose }\end{array}$ & 325 & 275 \\
\hline 7 & Starch & 50 & 50 \\
\hline 8 & $\begin{array}{l}\text { Crospovidone } \\
\text { Granulation }\end{array}$ & 20 & 20 \\
\hline 9 & $\begin{array}{l}\text { Water } \\
\text { Prelubrication }\end{array}$ & q.s. & q.s. \\
\hline 10 & Starch & 25 & 25 \\
\hline 11 & Aerosil & 10 & 10 \\
\hline 12 & $\begin{array}{l}\text { Talc } \\
\text { Lubrication }\end{array}$ & 15 & 15 \\
\hline 13 & Magnesium stearate & 5 & 5 \\
\hline Tablet & (mg) & 500 & 500 \\
\hline
\end{tabular}

\subsection{Physical characterization of polyherbal tablets}

Polyherbal tablets systems were characterized for thickness, diameter, disintegration time, weight variation, and friability. Crushing strength, thickness and friability were determined by Monsanto hardness tester, digital vernier calipers and friabilator respectively.

\subsection{Isolation and identification of quercetin from polyherbal tablet}

Weight accurately $500 \mathrm{mg}$ equivalent of polyherbal tablet was transferred to the $10 \mathrm{~mL}$ volumetric flask and dissolved in $10 \mathrm{~mL}$ methanol. This solution was sonicated for $10 \mathrm{~min}$ and filtered through Whatman No. 1 paper to get solution containing $10 \mathrm{mg} / \mathrm{mL}$. Concentrated solution obtained from polyherbal tablet was subjected to preparative TLC. Preparative TLC were performed on $20 \mathrm{~cm} \times 10 \mathrm{~cm}$ TLC aluminum plate coated with $200 \mu \mathrm{m}$ layer thickness of silica gel $60 \mathrm{~F} 254$ using toluene:ethyl acetate:formic acid, 5:4:0.1 (v/v/v) as mobile phase. The quantification was carried out by densitometric scanning in absorbance mode at wavelength $380 \mathrm{~nm}$. The silica in the respective marked area was scraped off and collected carefully in a test tube. The scraped silica, which contained the standard quercetin was extracted in methanol and filtered individually. The filtrates containing quercetin were evaporated under reduced pressure to obtain quercetin.

Melting point of quercetin was determined by open capillary method. Structural confirmation of the isolated quercetin was done by I.R. Spectroscopy and compared with that of standard.

\subsection{In-vivo hepatoprotective activity of polyherbal tablet formulations against paracetamol induced toxicity}

\subsubsection{Test animals}

Male Wistar rats (125-175 g) were used for determination of maximum tolerable dose (MTD) and evaluation of hepatoprotective activity. The animals were housed in polypropylene cages at $25{ }^{\circ} \mathrm{C} \pm 1{ }^{\circ} \mathrm{C}$ with the relative humidity of $55 \pm 5 \%$ under $12 \mathrm{~h} / 12 \mathrm{~h}$ light/dark cycle. They were received a standard chow and water ad libitum during experimentation. The food was with-drawn on the day before the experiment, but free access of water was allowed. A minimum of six animals was used in each group. Throughout the experiments, animals were processed according to the suggested international ethical guidelines for the care of laboratory animals. The study protocol was approved by the Institutional Animal Ethics Committee according to the regulation of Committee for the Purpose of Control and Supervision of Experiments on Animals (MPC 1007: dated: 30/01/2010).

\subsubsection{Preparation and administration of test samples}

Approved IAEC method was adopted for screening of hepatoprotective activity. Dried fractions were suspended in 1\% CMC solution before oral administration to animals. Animals were divided into five groups of six rats each were used for the study. Groups 1 and 2 received normal saline ( $1 \mathrm{~mL} / \mathrm{kg}$, orally) for 7 days. Groups 3, 4 and 5 received $100 \mathrm{mg} / \mathrm{kg}$ bw doses of silymarin, PTF1 (50 mg/kg bw doses) and PTF2 (100 mg/kg bw doses) orally, once a day for 7 days. On the fifth day, after the administration of the respective treatments, all the animals in groups II, III, IV and V were administered paracetamol (PCM) $2 \mathrm{~g} / \mathrm{kg}$ orally. On the seventh day, the blood samples were collected via orbital sinus puncture for the estimation of biochemical marker enzymes. Then the liver was carefully isolated and cleaned off extraneous tissue and preserved in $10 \%$ neutral formalin and then subjected to histopathological studies. $^{22,23}$ 


\subsubsection{Assessment of biochemical parameters of liver}

The enzymatic parameters of serums like serum glutamate pyruvate transaminase (SGPT), serum glutamate oxaloacetate transaminase (SGOT) and serum alkaline phosphatase (ALP) and nonenzymatic parameter like total bilirubin (TB) were assayed according to standard methods. ${ }^{24,25}$

\subsubsection{Statistical analysis}

The results are expressed as mean \pm S.E.M $(N=6)$. Statistical significance was determined by one-way analysis of variance with $P<0.01$ and $P<0.05$ considered significant followed by Dunnett Multiple Comparisons Test. The analysis was performed by Graph Pad InStat software.

\subsubsection{Stability study}

Stability studies were carried out at $25{ }^{\circ} \mathrm{C} \pm 2{ }^{\circ} \mathrm{C} / 60 \% \mathrm{RH} \pm 5 \%$ and $40{ }^{\circ} \mathrm{C} \pm 2{ }^{\circ} \mathrm{C} / 75 \% \mathrm{RH} \pm 5 \%$ for a specific time period of 30 days for selected (PF2) formulation. The selected samples were evaluated for physical appearance, hardness and disintegration time in every 10 days interval.

\section{Results and discussion}

\subsection{Phytochemical screening}

Preliminary phytochemical screening of alcoholic extract and its fractions showed the presence of flavonoids, steroids, terpenoids, tannins and phenolic compounds. The chemical tests and TLC analysis demonstrated that AcO fraction of B. monosperma, EtOAc fraction and n-ButOH fraction of B. variegata, DCM and EtOAC fractions of $O$. gratissimum were rich in phenolic compounds. The phenolic content in B. monosperma (acetone fraction), B. variegata (ethyl acetate and n-butanol fractions) and $O$. gratissimum (dichloromethane and ethyl acetate fractions) were found to be $452 \pm 1.6,712.4 \pm 2.4,442.5 \pm 1.1,735 \pm 2.1$ and $1365 \pm 1.4 \mathrm{mg}$ gallic acid/1 $\mathrm{g}$ fraction respectively. The flavonoid content in $B$. monosperma (acetone fraction), B. variegata (ethyl acetate and nbutanol fractions) and 0 . gratissimum (dichloromethane and ethyl acetate fractions) were found to be $251 \pm 1.8,417 \pm 2.2,227 \pm 3.2$, $394.5 \pm 2.4$ and $717 \pm 5.2 \mathrm{mg}$ quercetin $/ 1 \mathrm{~g}$ fraction respectively. The phenol and flavonoid contents are responsible for hepatoprotective activity; hence these solvent fractions were selected for further study.

\subsection{HPTLC analysis}

In HPTLC chromatogram, all tracks for standard quercetin at wavelength $380 \mathrm{~nm}$ were shown in Fig. 1A. The Rf value of standard quercetin was found to be 0.38 and peak area was 9726 (Fig. 1B). Acetone fraction of $B$. monosperma showed twelve peaks, the sixth peak Rf value (0.39) was coinciding with standard $R f$ value and its peak area was 9909 (Fig. 2A), ethyl acetate fraction of B. variegata showed eight peaks, the fourth peak Rf value $(0.38)$ was coinciding with standard $\mathrm{Rf}$ value of quercetin and its peak area was 7898 (Fig. 2B), n-butanol fraction of $B$. variegata showed six peaks, the third peak Rf value $(0.38)$ was coinciding with standard Rf value and its peak area was 7570 (Fig. 2C), dichloromethane fraction of $O$. gratissimum showed nine peaks, the third peak Rf value $(0.38)$ was coinciding with standard Rf value and its peak area was 9246 (Fig. 2D), ethyl acetate fraction of 0 . gratissimum showed seven peaks, the third peak Rf value (0.39) was coinciding with standard Rf value and its peak area was 12427 (Fig. 2E). The concentrations of quercetin in acetone fraction of $B$. monosperma, ethyl acetate and nbutanol fractions of $B$. variegata, dichloromethane and ethyl acetate fractions of 0 . gratissimum were found to be $0.395,0.1744,0.1382$, $0.3229,0.6734(\mu \mathrm{g} / 10 \mathrm{mg})$ respectively.

\subsection{Pre- and post-compression evaluation parameters}

Pre-compression parameters (angle of repose, bulk density, tapped density and \% compressibility) of powder blends and tablets showed satisfactory micromeritics properties as angle of repose of was less than $30^{\circ}$ and \% compressibility was in the range of $15-17 \%$. The physical properties (weight variation, thickness, diameter, crushing strength, friability) of polyherbal tablets shown in Table 2. Tablets are circular biconvex in shape, light greenish with few white spots and slightly dark greenish spots color for PTF-1 and light greenish with slightly dark greenish spots for PTF-2 tablets, odor and taste are characteristics for the formulations. They produced average weight between (506 \pm 3.77 and $500.6 \pm 0.02$ ); uniform thickness, crushing strength and acceptable friability (less than $1 \%$ ). Tablets were disintegrated between 2 and $4.5 \mathrm{~min}$.

\subsection{Identification of quercetin by FTIR}

The IR spectra of isolated compound (quercetin) from polyherbal tablet were displayed in Fig. 3. The spectrum was typical of a flavonoid structure. The spectra were recorded in the range from 4000 to $600 \mathrm{~cm}^{-1}$ and showed identical absorption bands with maxima at the following frequencies (max): 3392.35, 2380.76, $1658.94,1446.45,1378.65 \mathrm{~cm}^{-1}$. The peaks at 3392 and $2919 \mathrm{~cm}^{-1}$ are characteristic of the aromatic ring structure. The absorption maxima at 1610 and $1557 \mathrm{~cm}^{-1}$ indicate the presence of a quinoid structure and $-\mathrm{C}=\mathrm{C}-$ bonds, respectively. The absorption maximum at $1375 \mathrm{~cm}^{-1}$ is due to phenolic $\mathrm{OH}$ groups. Melting point of isolated compound was found to be $314{ }^{\circ} \mathrm{C}$.
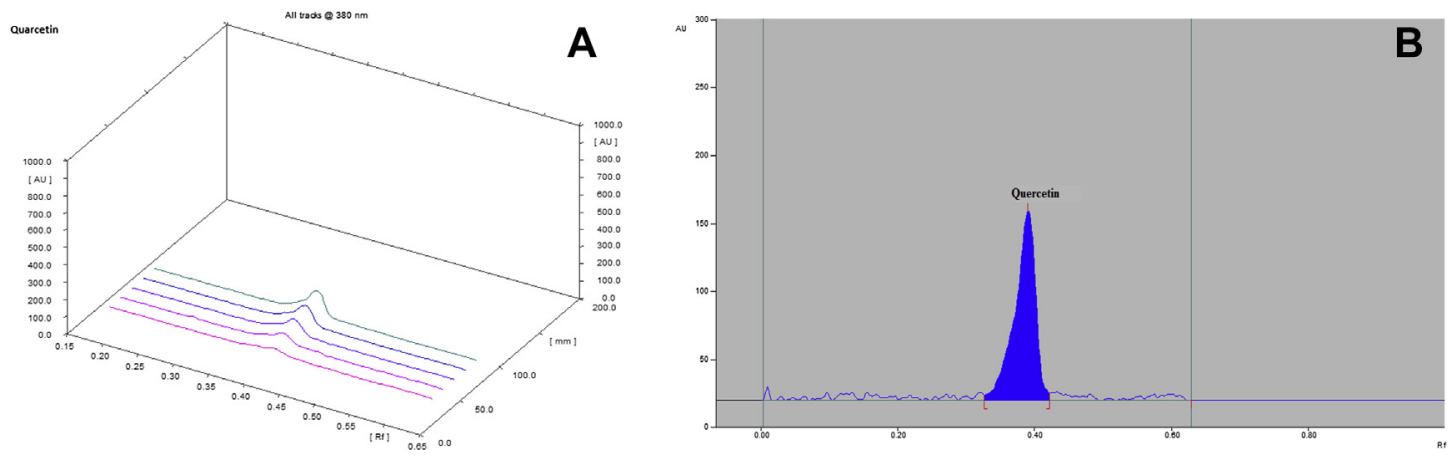

Fig. 1. 3D-chromatogram (A) and densitogram (B) of standard quercetin (0.5-2.5 $\mu \mathrm{g} / \mathrm{spot})$. 

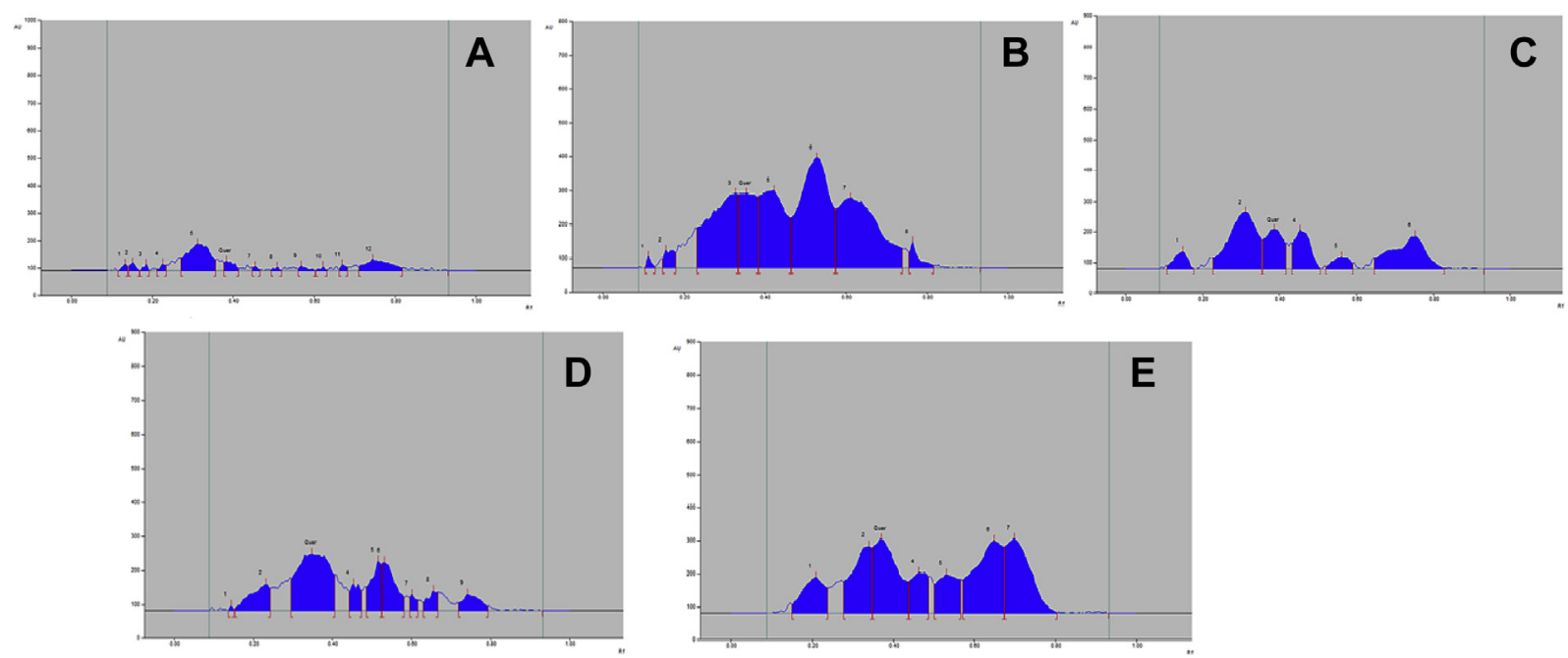

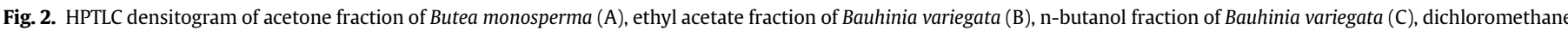
fraction of Ocimum gratissimum (D), ethyl acetate fraction of Ocimum gratissimum (E) showing quercetin.

Table 2

Pre- and post-compression evaluation of polyherbal tablet formulations PF1, PF2.

\begin{tabular}{|c|c|c|c|}
\hline SN & Quality control tests & PF1 & PF2 \\
\hline \multicolumn{4}{|c|}{ Pre-compression parameters of evaluation of polyherbal tablet formulations PF1, PF2 } \\
\hline 1. & Angle of repose (mean \pm S.D.) $(n=3)$ & $29.3 \pm 1.53$ & $28.7 \pm 0.58$ \\
\hline 2. & Bulk density (mean \pm S.D.) $(n=3)(\mathrm{g} / \mathrm{cc})$ & $0.427 \pm 0.003$ & $0.450 \pm 0.003$ \\
\hline 3. & Tapped density (mean \pm S.D. $)(n=3)(\mathrm{g} / \mathrm{cc})$ & $0.515 \pm 0.005$ & $0.523 \pm 0.008$ \\
\hline 4. & Compressibility index (\%) (mean \pm S.D. $)(n=3)$ & $17.15 \pm 0.2$ & $15.31 \pm 0.12$ \\
\hline \multicolumn{4}{|c|}{ Post-compression evaluation of tablets } \\
\hline 5. & Thickness $(\mathrm{mm})($ mean \pm S.D. $)(n=10)$ & $5.5 \pm 0.02$ & $5.6 \pm 0.03$ \\
\hline 6. & Diameter $(\mathrm{mm})($ mean \pm S.D. $)(n=10)$ & $11 \pm 0.04$ & $11 \pm 0.05$ \\
\hline 7. & Hardness $\left(\mathrm{kg} / \mathrm{cm}^{2}\right)($ mean \pm S.D. $)(n=10)$ & $3.1 \pm 0.19$ & $3.3 \pm 0.12$ \\
\hline 8. & Disintegration time $(\mathrm{min})($ mean \pm S.D. $)(n=6)$ & $2.10 \pm 0.42$ & $4.25 \pm 1.12$ \\
\hline 9. & Average weight $(\mathrm{mg})($ mean \pm S.D. $)(n=10)$ & $506 \pm 3.77$ & $500.6 \pm 0.02$ \\
\hline 10. & Friability $(\%)($ mean \pm S.D. $)(n=3)$ & $0.3 \pm 0.23$ & $0.2 \pm 0.16$ \\
\hline \multicolumn{4}{|c|}{ Physical parameters (appearance) of tablet formulations } \\
\hline 11. & Color & $\begin{array}{l}\text { Light greenish with few white spots } \\
\text { slightly dark greenish spots }\end{array}$ & $\begin{array}{l}\text { Light greenish with slightly } \\
\text { dark greenish spots }\end{array}$ \\
\hline 12. & Odor & Characteristic & Characteristic \\
\hline 13. & Shape & Circular biconvex tablet & Circular biconvex tablet \\
\hline 14. & Taste & Characteristic & Characteristic \\
\hline
\end{tabular}

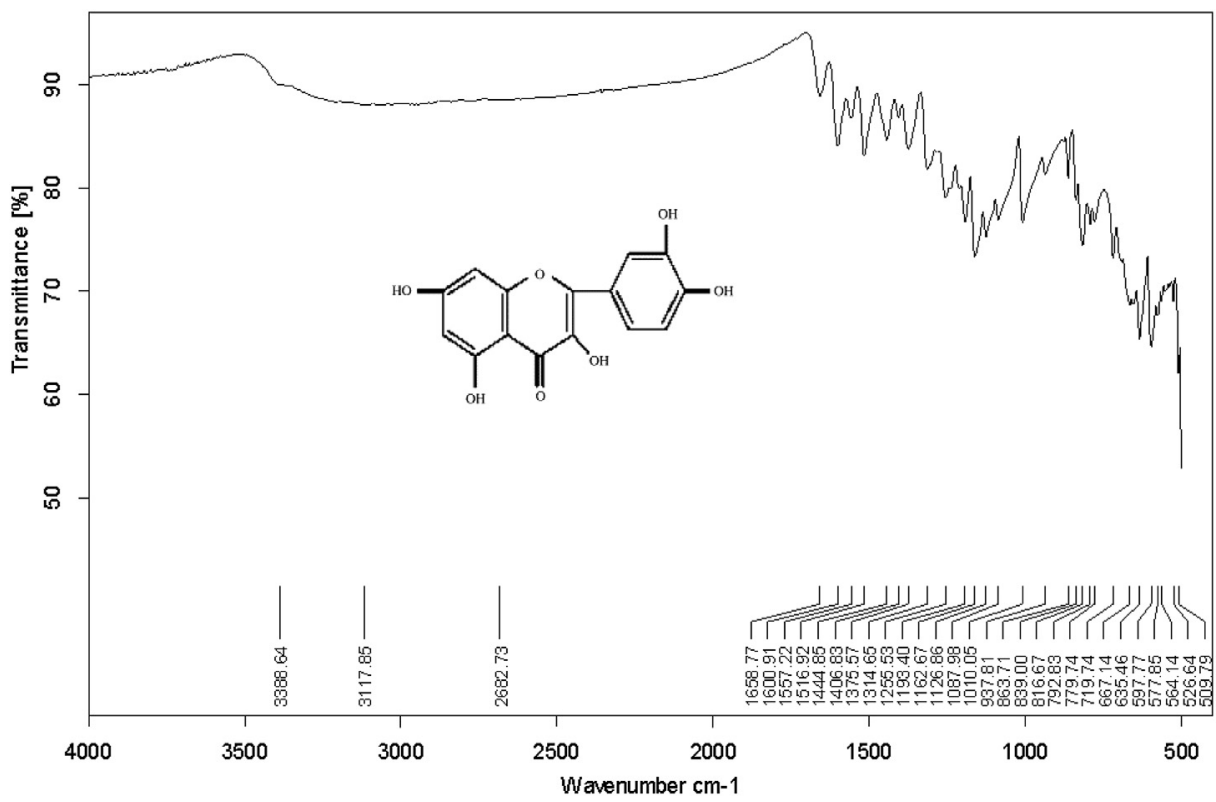

Fig. 3. IR spectrum of isolated compound from the mixture of fractions of Butea monosperma, Bauhinia variegata and Ocimum gratissimum. 
Table 3

Effect of polyherbal formulation PTF-1 and PTF-2 on biochemical parameters in paracetamol induced hepatic injury in rats.

\begin{tabular}{|c|c|c|c|c|c|}
\hline Treatment & SGPT U/L & SGOT U/L & ALP U/L & Total bilirubin (mg/dl) & Direct bilirubin $(\mathrm{mg} / \mathrm{dl})$ \\
\hline Control & $69.75 \pm 1.96$ & $135.67 \pm 1.63$ & $145.47 \pm 3.73$ & $0.89 \pm 0.07$ & $0.23 \pm 0.01$ \\
\hline Paracetamol treated & $284.25 \pm 1.38^{* *}$ & $421.18 \pm 1.12^{* * *}$ & $464.43 \pm 1.36^{* * *}$ & $3.74 \pm 0.92^{* * * *}$ & $0.65 \pm 0.03^{* * *}$ \\
\hline Silymarin treated & $71.46 \pm 0.81^{\# \#}$ & $142.63 \pm 0.82^{\# \#}$ & $174.73 \pm 1.24^{\# \#}$ & $1.25 \pm 0.83^{\#}$ & $0.29 \pm 0.05^{\# \#}$ \\
\hline PTF-1 treated & $75.85 \pm 1.35^{\# \#}$ & $149.63 \pm 1.73^{\# \#}$ & $180.64 \pm 1.25^{\mathrm{NS}}$ & $1.48 \pm 0.42^{\mathrm{NS}}$ & $0.32 \pm 0.03^{\mathrm{NS}}$ \\
\hline PTF-2 treated & $65.56 \pm 1.68^{\# \#}$ & $152.98 \pm 1.48^{\# \#}$ & $167.87 \pm 1.78^{\# \#}$ & $1.32 \pm 0.78^{\# \#}$ & $0.33 \pm 0.10^{\# \#}$ \\
\hline
\end{tabular}

${ }^{* * *} P<0.001$ vs control, ${ }^{\#} P<0.05,{ }^{\# \#} P<0.01$ vs PCM treated, NS non significant.

A

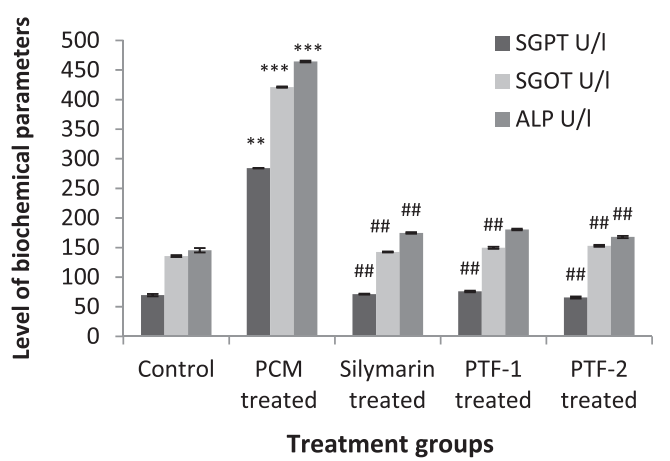

Effect of PTF-1 and PTF-2 on SGOT, SGPT and ALP(U/L) in paracetamol induced hepatic injury in rats.
B

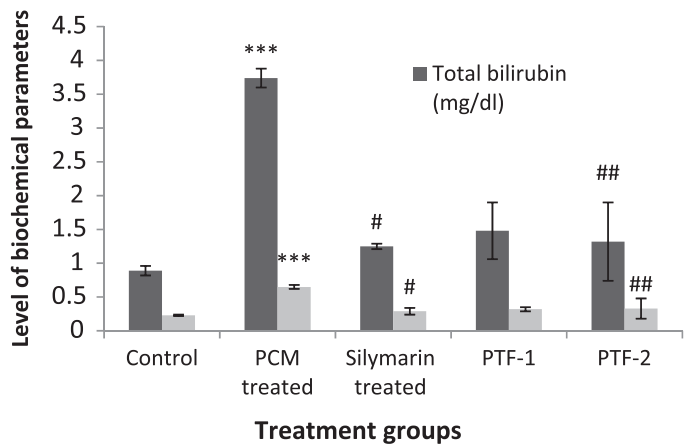

Effect of PTF-1 and PTF-2 on SGOT Total Bilirubin (mg/dl) in paracetamol induced hepatic injury in rats.

Fig. 4. Graphs showing effect of polyherbal formulation PTF-1 and PTF-2 on biochemical parameters in paracetamol induced hepatic injury in rats.

\subsection{Evaluation of hepatoprotective activity}

From the results of acute toxicity study by previously published literature, $2000 \mathrm{mg} / \mathrm{kg}$ was considered as maximum tolerable dose (MTD) of alcoholic extract of B. monosperma, ${ }^{14}$ B. variegata ${ }^{26}$ and $O$. gratissimum. ${ }^{27} 1 / 20$ th of this dose was taken as experimental dose for subsequent hepatoprotective studies. The effective dose of each fraction was decided on the basis of previously published report, i.e. $100 \mathrm{mg} / \mathrm{kg}$ of body weight.

Paracetamol has enhanced the levels of SGPT, SGOT, bilirubin (both total and direct bilirubin levels), alkaline phosphatase level (ALP). The results indicated that the polyherbal tablet formulations
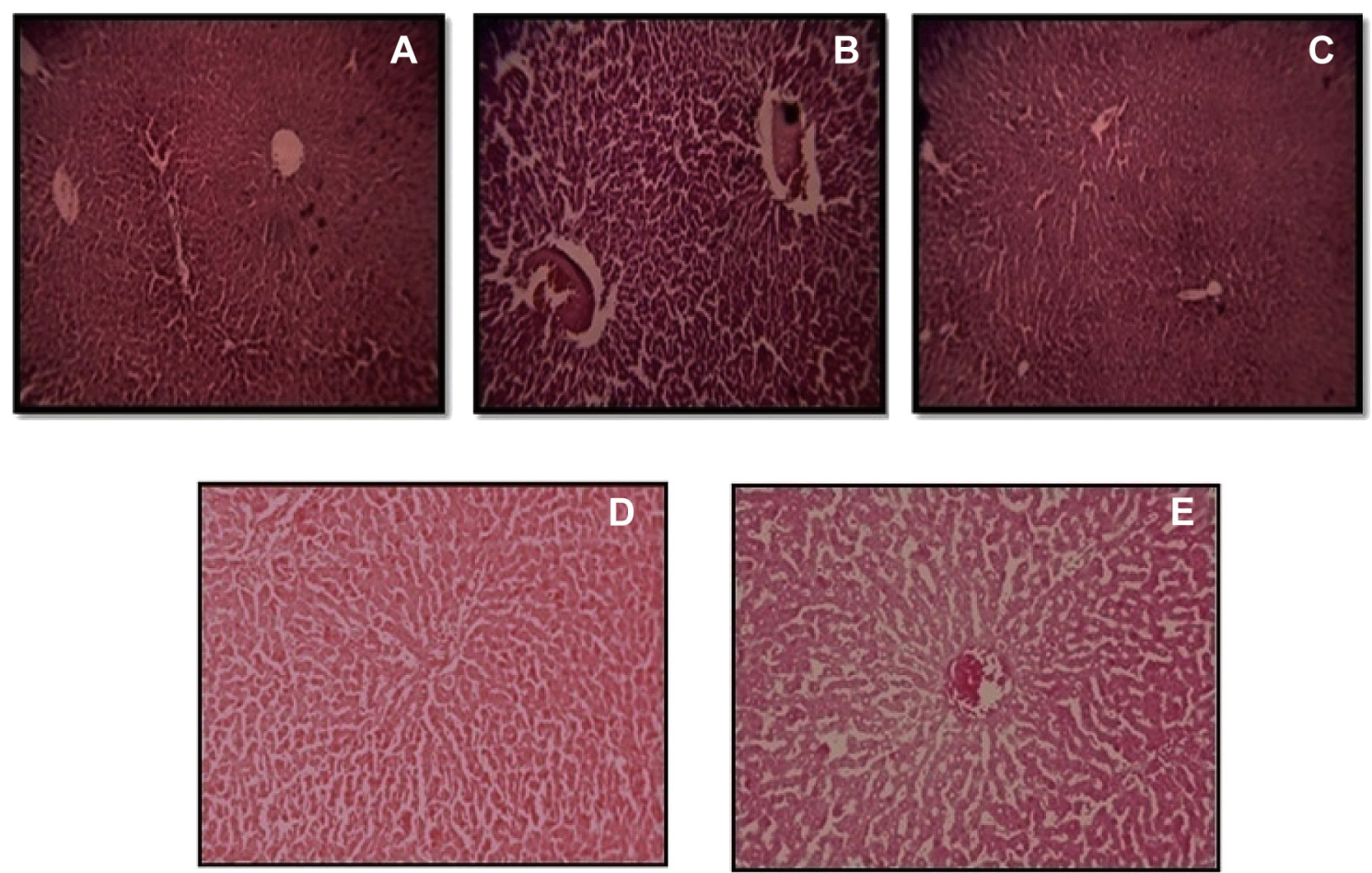

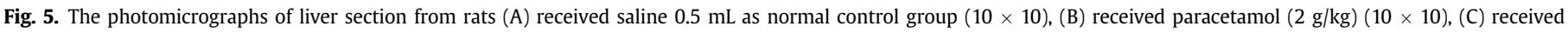
silymarin $(100 \mathrm{mg} / \mathrm{kg} \mathrm{bw})+$ PCM $(10 \times 10)$, (D) received PF1 $(50 \mathrm{mg} / \mathrm{kg} \mathrm{bw})+$ PCM and (E) received PF2 $(100 \mathrm{mg} / \mathrm{kg}$ bw). 
Table 4

Histopathological changes in the liver of rats treated with polyherbal formulation PTF-1 and PTF-2.

\begin{tabular}{llllll}
\hline Microscopic observation & Control & PCM & Silymarin & PTF-1 & PTF-2 \\
\hline Degeneration in hepatocytes & + & +++ & ++ & ++ & ++ \\
Hepatic cell injury & $\emptyset$ & +++ & ++ & + & ++ \\
Focal necrosis & $\emptyset$ & +++ & $\emptyset$ & ++ & + \\
Congestion in central vein & + & +++ & + & ++ & ++ \\
Vascular swelling & + & +++ & + & + & ++ \\
Kupffer cell proliferation & $\emptyset$ & ++ & + & ++ & + \\
\hline
\end{tabular}

$\emptyset$, absent; $\perp$, few; + , mild; ++ , moderate; +++ , severe; ++++ , extremely severe, PCM - paracetamol.

(PTF-1 and PTF-2) significantly reduced the elevated levels of SGPT, SGOT, ALP and bilirubin when compared to paracetamol treated group. The formulation PTF-1 has reduced the increased SGPT level from $284.25 \mathrm{U} / \mathrm{L}$ to $75.85 \mathrm{U} / \mathrm{L}$, SGOT level from $421.18 \mathrm{U} / \mathrm{L}$ to $149.63 \mathrm{U} / \mathrm{L}$, ALP level from $464.43 \mathrm{U} / \mathrm{L}$ to $180.64 \mathrm{U} / \mathrm{L}$ and bilirubin level from $3.74 \mathrm{mg} / \mathrm{dl}$ to $1.48 \mathrm{mg} / \mathrm{dl}$. The formulation PTF-2 has reduced the increased SGPT level from $284.25 \mathrm{U} / \mathrm{L}$ to $65.56 \mathrm{U} / \mathrm{L}$, SGOT level from $421.18 \mathrm{U} / \mathrm{L}$ to $152.98 \mathrm{U} / \mathrm{L}$, ALP level from $464.43 \mathrm{U} / \mathrm{L}$ to $167.87 \mathrm{U} / \mathrm{L}$ and bilirubin level from $3.74 \mathrm{mg} / \mathrm{dl}$ to $1.32 \mathrm{mg} / \mathrm{dl}$.

Hepatic cells participate in metabolic activities and contain host of enzymes. In tissue, SGOT and SGPT exist in mitochondria. In liver injury, transport function of the hepatocytes gets disturbed, resulting in the leakage of plasma membrane and thereby causing an increased enzyme level in serum. The elevated activities of these enzymes are indicative of cellular leakage and the functional integrity of the cell membranes in liver. ALP is excreted by liver via bile in the liver injury due to hepatotoxins, which results in a defective excretion of bile by the liver and is reflected in their increased levels in serum. In drug-induced liver toxicity, the level of total and direct bilirubin gets elevated. Both formulations showed marked decrease in the elevated levels of SGOT, SGPT, ALP and bilirubin (total and direct) which is nearer to the levels of control group. ${ }^{28}$ The results are shown in Table 3, Fig. 4.

Histopathological examination of the liver sections confirmed that the normal liver (Fig. 5A) architecture was damaged with paracetamol administration (Table 4, Fig. 5B). However, pretreatment of the PTF1 $(50 \mathrm{mg} / \mathrm{kg})$ and PTF2 $(100 \mathrm{mg} / \mathrm{kg})$ dose significantly reduced the severity of histopathological injury (compared with the paracetamol group). The results of the biochemical tests and histopathological observations suggest that PTF2 formulation is better than PTF1.

Rats treated with silymarin, PTF-1 and PTF-2 formulations showed noticeable improvement in histopathological parameters (Table 4 and Fig. 5C-E). Therefore, both the formulations have

\section{Table 5}

Stability studies data for PTF-2 formulation at $25^{\circ} \mathrm{C} / 60 \% \mathrm{RH}$.

\begin{tabular}{|c|c|c|c|c|}
\hline \multirow[t]{2}{*}{ Parameter } & \multicolumn{4}{|l|}{ PTF-2 } \\
\hline & 0 day & 10 days & 20 days & 30 days \\
\hline \multicolumn{5}{|c|}{ Stability studies data for PTF-2 formulation at $25^{\circ} \mathrm{C} / 60 \% \mathrm{RH}$} \\
\hline Appearance & * & $* *$ & ** & $* *$ \\
\hline $\begin{array}{l}\text { Hardness }\left(\mathrm{kg} / \mathrm{cm}^{2}\right) \\
\quad(n=3)(\text { mean } \pm \text { S.D. })\end{array}$ & $3.3 \pm 0.12$ & $3.3 \pm 0.15$ & $3.3 \pm 0.12$ & $3.6 \pm 0.06$ \\
\hline $\begin{array}{l}\text { Disintegration time } \\
\quad(\min )(n=3) \\
\quad(\text { mean } \pm \text { S.D. })\end{array}$ & $2.12 \pm 0.12$ & $3.32 \pm 0.15$ & $2.33 \pm 0.12$ & $2.20 \pm 0.06$ \\
\hline \multicolumn{5}{|c|}{ Stability studies data for PTF-2 formulation $40^{\circ} \mathrm{C} / 75 \% \mathrm{RH}$} \\
\hline Appearance & * & $* *$ & $* *$ & $* * *$ \\
\hline $\begin{array}{l}\text { Hardness }\left(\mathrm{kg} / \mathrm{cm}^{2}\right) \\
\quad(n=3)\end{array}$ & $3.4 \pm 0.12$ & $3.3 \pm 0.15$ & $3.5 \pm 0.23$ & $3.8 \pm 0.15$ \\
\hline $\begin{array}{l}\text { Disintegration time } \\
\quad(\min )(n=3)\end{array}$ & $4.00 \pm 0.58$ & $4.30 \pm 0.83$ & $4.36 \pm 0.86$ & $5.30 \pm 1.69$ \\
\hline
\end{tabular}

*Light greenish color with slightly dark greenish spots, ${ }^{* *}$ No change, ${ }^{* * *}$ Light greenish color with dark greenish spots. prominent action on paracetamol-induced liver damage. Moreover, at necropsy, livers of rats treated with paracetamol appeared degeneration in hepatocytes, hepatic cell injury, focal necrosis, congestion in central vein, vascular swelling, and Kupffer cell proliferation. Furthermore, no gross pathological findings were noted in the livers of the other groups of rats.

\subsection{Stability studies}

Selected polyherbal tablet formulation PTF-2 was found to be stable when subjected to stability studies at $25{ }^{\circ} \mathrm{C} / 60 \% \mathrm{RH}$ and $40{ }^{\circ} \mathrm{C} / 75 \% \mathrm{RH}$ for a time period of 30 days. There was no significant change in the physicochemical properties of tablets i.e. appearance, disintegration time and hardness of the tablets. The results are shown in Table 5.

\section{Conclusion}

Biochemical marker showed improved results for polyherbal tablet formulation at $100 \mathrm{mg} / \mathrm{kg}$. Polyherbal tablet formulation contains a potent hepatoprotective agent suggested to be a flavone concentrated in polyherbal formulation which may find clinical application in amelioration of paracetamol induced liver damage.

\section{Authors contribution}

Principle investigator and project leader: Mrs. Arti Gupta. Concept development: Dr. Navin R. Sheth.

Analysis and written the manuscript: Mrs. Sonia Pandey.

Statistical analysis: Mr. Jitendra S. Yadav and Dr. Dinesh Shah.

\section{Conflicts of interest}

All authors have none to declare.

\section{Acknowledgment}

Dr. Minoo H. Parabia, Professor, Department of Bioscience, Veer Narmad South Gujarat University, Surat and Dr. Renu Chauhan, Quality Assurance Department are acknowledged for their help.

\section{References}

1. Padh H, Patel B. Herbal drugs. Curr Sci. 2001;81:15. Bangalore.

2. Thaibinh T. Herbal medicine. Indian J Pharm Educ. 1998;32:104-106.

3. Chandira M, Jayakar B. Formulation and evaluation of herbal tablets containing Ipomoea digitata Linn. extract. Int I Pharm Sci Rev Res. 2010:3:101-110.

4. Bhope SG, Nagore DH, Kuber VV, Gupta PK, Patil MJ. Design and development of a stable polyherbal formulation based on the results of compatibility studies. Pharmacognosy Res. 2011;3:122.

5. WPR/RC52/7, WHO Regional Committee. 52nd Session Brunei Darussalam. World Health Organization (WHO); 2001.

6. Dutta NK, Mazumdar K, Mishra US, Dastidar SG, Park JH. Isolation and identification of flavones (quercetin) from Butea frondosa bark. J Pharm Chem. 2007;41:37-39.

7. Nadkarni KM. Indian Materia Medica. 2002; vol. I:223-225.

8. Gupta A, Sheth N, Pandey S, et al. Evaluation of protective effect of Butea monosperma (lam.) Taub in experimental hepatotoxicity in rats. J Pharmacol Pharmacother. 2012;3:183.

9. Bodakhe SH, Ram A. Hepatoprotective properties of Bauhinia variegata bark extract. Yakugaku Zasshi J Pharm Soc Jpn. 2007;127:1503-1507.

10. Maldonadu PD, Barrera D, Rivero I, Mata R, Copos ON, Pando RH. Antioxidant S-allylcysteine prevents gentamicin-induced oxidative stress and renal damage. Biomed. 2003;35:317-324.

11. Vilas SA, Dilpesh J. Protective effect of Ocimum gratissimum against carbon tetrachloride induced hepatic damage in rats. Pharmacol online. 2010;2:11111119.

12. Grayer RJ, Kite GC, Abou-Zaid M, Archer LJ. The application of atmospheric pressure chemical ionisation liquid chromatography-mass spectrometry in the chemotaxonomic study of flavonoids: characterisation of flavonoids from Ocimum gratissimum var. gratissimum. Phytochem Anal. 2000;11:257-267. 
13. Janbaz K, Saeed S, Gilani A. Studies on the protective effects of caffeic acid and quercetin on chemical-induced hepatotoxicity in rodents. Phytomed Int J Phytother Phytopharmacol. 2004;11:424-430.

14. Muralidhar A, Babu KS, Sankar TR, Reddanna P, Latha J. Evaluation of wound healing properties of bioactive fractions from the extract of Butea monosperma (lam) stem bark. Int J Phytomed. 2011;3:41-49.

15. Sharma N, Bhardwaj R, Kumar S, Kaur S. Evaluation of Bauhinia variegata L. bark fractions for in vitro antioxidant potential and protective effect against $\mathrm{H}_{2} \mathrm{O}_{2}$-induced oxidative damage to pBR322 DNA. Afr J Pharm Pharmacol. 2011;5:1494-1500.

16. Silva MGV, Vieira IG, Mendes FN, et al. Variation of quercetin content in eight Ocimum species from northeastern Brazil. Molecules. 2008;13:2482-2487.

17. Khandelwal K. Practical Pharmacognosy: Techniques and Experiments. vol. 8. Nirali Prakashan; 2001:3-40, 146-161.

18. Macdonald IO, Oludare AS, Olabiyi A. Phytotoxic and anti-microbial activities of flavonoids in Ocimum gratissimum. Life Sci J. 2010;7:3.

19. Yuvaraj P, Louis T, Madhavachadran V, Gopinath N, Rekha S. Total phenolic content and screening of antioxidant activity of selected ayurvedic medicinal plants. Ayurvedic Renaissance. 2011;91:25.

20. Kosalec I, Bakmaz M, Pepeljnjak S, Vladimir-Knezevic S. Quantitative analysis of the flavonoids in raw propolis from northern Croatia. Acta Pharm Zagreb. 2004;54:65-72.
21. Lachman L, Lieberman HA, Kanig JL. The Theory and Practice of Industrial Pharmacy. Special Indian Edition. 2009:318-321.

22. Chattopadhyay R. Possible mechanism of hepatoprotective activity of Azadirachta indica leaf extract: part II. J. Ethnopharmacol. 2003;89:217-219.

23. Parasuraman S, Raveendran R, Kesavan R. Blood sample collection in small laboratory animals. J Pharmacol Pharmacother. 2010;1:87.

24. Puratchikody A, Devi CN, Nagalakshmi G. Wound healing activity of Cyperus rotundus Linn. Indian J Pharm Sci. 2006;68:97.

25. Varley H, Van E, Kass I. Practical Clinical Chemistry. vol. 1. London: William Heinemann Medical Books; 1994:891-907.

26. Balamurugan G, Muralidharan P. Antiobesity effect of Bauhinia variegata bark extract on female rats fed on hypercaloric diet. Bangladesh J Pharmacol. 2010;5: $8-12$.

27. Okoli C, Ezike A, Agwagah O, Akah P. Anticonvulsant and anxiolytic evaluation of leaf extracts of Ocimum gratissimum, a culinary herb. Pharmacognosy Res. 2010;2:36.

28. Tatiya AU, Surana SJ, Sutar MP, Gamit NH. Hepatoprotective effect of poly herbal formulation against various hepatotoxic agents in rats. Pharmacognosy Res. 2012;4:50. 